\title{
Regulatory interactions between the Hrp type III protein secretion system and coronatine biosynthesis in Pseudomonas syringae pv. tomato DC3000
}

\author{
Alejandro Peñaloza-Vázquez, ${ }^{1}$ Gail M. Preston, ${ }^{2}$ Alan Collmer ${ }^{3}$ \\ and Carol L. Bender ${ }^{1}$
}
1 Department of Entomology and Plant Pathology, 110 Noble Research Center, Oklahoma State University, Stillwater OK 74078-3032, USA
2 Department of Plant Sciences, University of Oxford, South Parks Road, Oxford OX1 3RB, UK
3 Department of Plant Pathology, Cornell University, Ithaca, NY 14853-4203, USA

\author{
Author for correspondence: Carol L. Bender. Tel: +1 405744 9945. Fax: +1 4057447373. \\ e-mail: cbender@okstate.edu
}

In $P$. syringae, the co-ordinated regulation of different systems required for pathogenicity and virulence seems logical but has not been established. This question was addressed in the present study by analysing production of the phytotoxin coronatine (COR) in defined hrp/hrc mutants of $P$. syringae pv. tomato DC3000. COR was produced in vitro by mutants of DC3000 defective in hrcC, which encodes an outer-membrane protein required for type III-mediated secretion. When inoculated in plants, hrcC mutants produced chlorotic regions indicative of COR production, but lacked the necrotic lesions produced by the wild-type DC3000. Furthermore, a DC3000 mutant containing a polar mutation in $h r c C$, which inactivates $h r c C, h r p T$ and $h r p V$, produced significantly higher amounts of COR than the wild-type strain in vitro. This mutant was able to produce COR earlier and at lower cell densities than the wild-type. The results indicate that the hrp/hrc secretion system is not required for COR production, but mutations in this system may have regulatory effects on the production of virulence factors such as COR.

Keywords: type III secretion system, phytotoxin, virulence

\section{INTRODUCTION}

Pseudomonas syringae is a Gram-negative, necrogenic bacterium that elicits a wide variety of symptoms in plants, including blights (rapid death of tissue), leaf spots and galls. The species is divided into pathogenic variants (pathovars) which vary in host range. The genetic basis of pathogenicity and virulence in $P$. syringae is complex and includes global regulators (Hrabak \& Willis, 1992; Kitten et al., 1998; Rich et al., 1994), the hrp cluster and virulence factors such as phytotoxins and exopolysaccharides (Bender et al., 1999; Yu et al., 1999). The hrp region (bypersensitive response and pathogenicity) is conserved in phytopathogenic prokaryotes and affects the ability of a bacterium to induce a hypersensitive response (HR) in non-host plants, pathogenicity on host plants and the

\footnotetext{
Abbreviations: COR, coronatine; CFA, coronafacic acid; CMA, coronamic acid; GUS, glucuronidase; HR, hypersensitive response; HSS medium, Hoitink-Sinden medium amended with sucrose; MG medium, mannitolglutamate medium.
}

ability to grow within or on the surface of plants (He, 1998; Hirano et al., 1999). A subset of the hrp genes was renamed hrc (HR and conserved) because of their conservation in the type III secretion apparatus used by Yersinia, Shigella and Salmonella (Bogdanove et al., 1996; Galán \& Collmer, 1999).

The hrp/hrc gene cluster has been most extensively characterized in $P$. syringae pv. syringae Pss61 where it is located in a $25 \mathrm{~kb}$ region of the chromosome and consists of 27 genes organized into eight transcriptional units (Galán \& Collmer, 1999; Hutcheson, 1999). Activities in the type III secretion apparatus have been assigned to some of the $\mathrm{Hrc}$ proteins. For example, $\operatorname{brcC}$ encodes an outer-membrane protein that is essential for type III protein secretion and has a primary role in protein translocation across the outer membrane (Charkowski et al., 1997). The hrcC gene in P. syringae pv. syringae Pss61 and pv. tomato DC3000 is flanked by four genes, $h r p F, \operatorname{hrp} G, \operatorname{hrp} T$ and $h r p V$, which constitute an operon (brpFGCTV) (Alfano et al., 2000; Preston, 1997; Yuan \& He, 1996). hrpF, hrpG and hrp $T$ are thought to encode components of the type III 
secretion system, whereas $\mathrm{HrpV}$ functions as a negative regulator (Preston et al., 1998).

The $h r p / h r c$ gene cluster is environmentally regulated in $P$. syringae and these genes are rapidly induced following infiltration into host tissue (Hutcheson et al., 1996). Several genes in the hrp cluster mediate environmental regulation of the hrp/hrc regulon. HrpR and HrpS show similarity to response regulators in two-component regulatory systems and function as transcriptional activators of hrpL (Xiao et al., 1994). hrpL encodes a $\sigma$ factor related to the extracellular factor family of alternate $\sigma$ factors and is required for expression of several transcripts in the hrp gene cluster (Hutcheson, 1999; Xiao et al., 1994). HrpV is a negative regulator of hrp gene expression that presumably functions upstream of HrpR and HrpS in the hrp regulon (Deng et al., 1998; Preston et al., 1998). hrpA encodes the structural protein of the Hrp pilus and is also thought to mediate the expression of $\operatorname{rrpR}$ and hrpS (Roine et al., 1997; Wei et al., 2000).

In addition to the hrp/hrc genes, many P. syringae strains produce low-molecular-mass, non-host specific phytotoxins that induce chlorosis or necrosis (Bender et al., 1999). The phytotoxin coronatine (COR) is a virulence factor produced by several $P$. syringae pathovars, including atropurpurea, glycinea, maculicola, morsprunorum and tomato which infect ryegrass, soybeans, crucifers, Prunus spp. and tomato, respectively (Bender et al., 1999). The primary symptom elicited by COR is a diffuse chlorosis that can be induced on a wide variety of plant species. COR also induces hypertrophy, inhibits root elongation and stimulates ethylene production in some but not all plant species (Kenyon \& Turner, 1992).

COR consists of two distinct structural components that function as biosynthetic intermediates: (1) the polyketide coronafacic acid (CFA) and (2) coronamic acid (CMA), an ethylcyclopropyl amino acid derived from isoleucine (Mitchell, 1985; Parry et al., 1994). The biosynthesis of COR has been intensively studied in $P$. syringae pv. glycinea PG4180 where the $32 \mathrm{~kb}$ COR gene cluster contains two distinct regions that encode the structural genes for CMA and CFA biosynthesis (Bender et al., 1999). The CFA and CMA gene clusters in PG4180 are separated by a $3.4 \mathrm{~kb}$ region that controls both CFA and CMA production, and the nucleotide sequence of this region revealed the presence of three regulatory genes, corP, corS and corR (Ullrich et al., 1995). The deduced amino acid sequences of corP and corR indicated relatedness to response regulators which function as members of two-component regulatory systems, and the translational product of $\operatorname{cor} S$ showed similarity to histidine protein kinases which function as environmental sensors (Ullrich et al., 1995). Complementation analysis using a corR mutant and transcriptional fusions to a promoterless glucuronidase (GUS) gene (uidA) indicated that CorR functions as a positive regulator of CFA and CMA gene expression (Peñaloza-Vázquez \& Bender, 1998; Wang et al., 1999).
Although some of the signals for virulence factor production have been defined, the mechanisms used for integration of these signals remain unclear. An especially intriguing question is the potential relationship between virulence factors such as COR and the type III secretion system encoded by the hrp/hrc gene cluster. The coordinated regulation of the $h r p / h r c$ cluster, which is required for pathogenicity, and virulence factors such as COR seems logical but has not been established. In this study, we investigated the effect of $h r p / h r c$ mutations on the expression and biosynthesis of COR in P. syringae pv. tomato DC3000.

\section{METHODS}

Bacterial strains and culture conditions. The bacterial strains and plasmids used in this study are listed in Table 1. Escherichia coli strains were maintained in Luria-Bertani medium or Terrific Broth (Sambrook et al., 1989). P. syringae pv. tomato strains were routinely maintained at $28^{\circ} \mathrm{C}$ on King's Medium B (King et al., 1954), which contains the following ingredients $\left(\mathrm{l}^{-1}\right): 20 \mathrm{~g}$ proteose peptone no. 3 (Becton Dickinson), $1.5 \mathrm{~g} \mathrm{~K}_{2} \mathrm{HPO}_{4}, 1.5 \mathrm{~g} \mathrm{MgSO}_{4} .7 \mathrm{H}_{2} \mathrm{O}$ and $15 \mathrm{ml}$ glycerol. Prior to plant experiments, Pseudomonas strains were cultured on mannitol-glutamate $(\mathrm{MG})$ medium (Keane et al., 1970), a minimal medium containing the following nutrients $\left(\mathrm{l}^{-1}\right): 10 \mathrm{~g}$ mannitol, $2 \cdot 0 \mathrm{~g} \mathrm{~L}$-glutamic acid (monosodium salt), $0.5 \mathrm{~g} \mathrm{KH}_{2} \mathrm{PO}_{4}, 0.2 \mathrm{~g} \mathrm{NaCl}$ and $0.2 \mathrm{~g}$ $\mathrm{MgSO}_{4} \cdot 7 \mathrm{H}_{2} \mathrm{O}$. The $\mathrm{pH}$ of $\mathrm{MG}$ medium was adjusted to $7 \cdot 0$ with $3 \mathrm{M} \mathrm{NaOH}$ prior to autoclaving. In experiments where COR production or GUS activity were quantified, derivatives of $P$. syringae pv. tomato DC3000 were grown in HoitinkSinden medium amended with sucrose (HSS), which contained the following nutrients $\left(1^{-1}\right): 1 \cdot 0 \mathrm{~g} \mathrm{NH}_{4} \mathrm{Cl}, 0 \cdot 2 \mathrm{~g}$ $\mathrm{MgSO}_{4} .7 \mathrm{H}_{2} \mathrm{O}, 4 \cdot 1 \mathrm{~g} \mathrm{KH}_{2} \mathrm{PO}_{4}, 3 \cdot 6 \mathrm{~g} \mathrm{~K}_{2} \mathrm{HPO}_{4} .3 \mathrm{H}_{2} \mathrm{O}, 3.42 \mathrm{~g}$ sucrose and $2 \mu \mathrm{M} \mathrm{FeCl}_{3}$. The $\mathrm{pH}$ was adjusted to 6.5 with $10 \mathrm{M} \mathrm{NaOH}$ before autoclaving and a stock solution containing sucrose was autoclaved separately. The density of bacterial cell suspensions was determined with a Spectronic 20 spectrophotometer (Bausch \& Lomb), using a cuvette with a $13 \mathrm{~mm}$ path length. When appropriate, antibiotics were added at the following concentrations $\left(\mu \mathrm{g} \mathrm{ml}^{-1}\right)$ : rifampicin, 100; chloramphenicol, 25; kanamycin, 25; tetracycline, 25; spectinomycin, 25.

Molecular genetic techniques. Electrophoresis and smallscale plasmid DNA preparations were performed by standard procedures (Sambrook et al., 1989). Plasmids were transformed into $P$. syringae by electroporation as described by Sambrook et al. (1989).

Quantitative analysis of COR. P. syringae pv. tomato DC3000 and derivatives were grown at $18^{\circ} \mathrm{C}$ in HSS medium and supernatants were analysed for COR production by HPLC (Palmer \& Bender, 1993). COR production was normalized for differences in bacterial growth by expressing the quantity as a function of protein concentration (Peñaloza-Vázquez \& Bender, 1998). The protein content in bacterial cell lysates was determined with the Bio-Rad Protein Assay Kit.

Kinetics of COR production. P. syringae pv. tomato DC3000 and DC3000-hrcC were grown for $30 \mathrm{~h}$ on MG agar containing rifampicin and chloramphenicol, respectively. The bacteria were then resuspended in HSS medium to an $\mathrm{OD}_{600}$ of $0 \cdot 1$ and incubated with shaking (250 r.p.m.) at $18^{\circ} \mathrm{C}$ for $10 \mathrm{~d}$. Aliquots of the two strains (three replicates per sampling) were removed at $6,12,24,48,72,120,168$ and $240 \mathrm{~h}$, and 
Table 1. Bacterial strains and plasmids used in this study

\begin{tabular}{|c|c|c|}
\hline Strain or plasmid & Relevant characteristics* & Reference or source \\
\hline \multicolumn{3}{|l|}{ E. coli } \\
\hline DH $5 \alpha$ & & Sambrook et al. (1989) \\
\hline JM109 & & Stratagene \\
\hline \multicolumn{3}{|c|}{ P. syringae pv. tomato } \\
\hline DC3000 & $\operatorname{Rif}^{r} ; \mathrm{COR}^{+}$ & Moore et al. (1989) \\
\hline D3000-hrcC & $\mathrm{Cm}^{\mathrm{r}} ; \operatorname{hrc} C:: \operatorname{Tn} 5 \mathrm{Cm}$ & Yuan \& He (1996) \\
\hline DC3682 & $\mathrm{Km}^{\mathrm{r}} ; \mathrm{COR}^{-} \mathrm{Tn} 5$ mutant of DC3000 & Ma et al. (1991) \\
\hline CUCPB5112 & $\begin{array}{l}\mathrm{Km}^{\mathrm{r}} ; h r c \Delta:: n p t I I ; 1.8 \mathrm{~kb} \text { of } h r c C \text { was } \\
\text { replaced with } n p t I I \text { from pCPP2988 }\end{array}$ & $\begin{array}{l}\text { W.-L. Deng, Cornell } \\
\text { University, NY, USA }\end{array}$ \\
\hline PT23.26 & $\mathrm{Km}^{\mathrm{r}} ; \mathrm{COR}^{-} \mathrm{Tn} 5$ mutant of PT23.2 & Bender et al. (1989) \\
\hline \multicolumn{3}{|l|}{ Plasmids } \\
\hline pCPP2371 & $\begin{array}{l}\mathrm{Gm}^{\mathrm{r}} \text {, contains } h r p V \text { expressed from } n p t I I \\
\text { promoter in pML122 }\end{array}$ & Preston et al. (1998) \\
\hline pRGMU1 & $\begin{array}{l}\mathrm{Sm}^{\mathrm{r}} \mathrm{Sp}^{\mathrm{r}} \text {; contains a } 2 \cdot 9 \mathrm{~kb} \text { Pst } \mathrm{I} \text { insert with the } \\
\text { cmaABT promoter from the COR gene } \\
\text { cluster in pRG960sd }\end{array}$ & Ullrich \& Bender (1994) \\
\hline
\end{tabular}

*Cm, Chloramphenicol; Gm, gentamycin; Km, kanamycin; Rif, rifampicin; Sm, streptomycin; Sp, spectinomycin.

evaluated for growth by dilution plating and for COR production by HPLC.

COR production at different inoculum densities. To evaluate the effect of inoculum density on COR production, $P$. syringae pv. tomato DC3000 and DC3000-hrcC were grown for $30 \mathrm{~h}$ on MG agar and resuspended in HSS broth to an $\mathrm{OD}_{600}$ of $2 \cdot 5$. Tenfold serial dilutions of bacterial suspensions were made in HSS broth, aliquots of each dilution were removed and bacterial concentrations were determined by dilution plating. Each dilution was incubated for $72 \mathrm{~h}$ at $18{ }^{\circ} \mathrm{C}$ (250 r.p.m.) and analysed for COR by HPLC.

GUS assays. pRGMU1, which contains the cmaABT:: uidA promoter fusion, was previously shown to be transcriptionally active in DC3000 (Rohde et al., 1998). In the present study, DC3000 and DC3000-hrcC containing pRGMU1 were grown for $24 \mathrm{~h}$ on $\mathrm{MG}$ agar containing spectinomycin, inoculated $\left(\mathrm{OD}_{600}=0 \cdot 1\right)$ in HSS medium and incubated at $18^{\circ} \mathrm{C}(250$ r.p.m.). Aliquots of cells (three replicates per sampling) were removed at 12, 24, 72 and $120 \mathrm{~h}$ after inoculation and analysed for GUS activity as described previously (Palmer et al., 1997). GUS activity was expressed in $\mathrm{U}(\mathrm{mg} \text { protein })^{-1}$ with $1 \mathrm{U}$ equivalent to $1 \mathrm{nmol}$ methylumbelliferone formed $\mathrm{min}^{-1}$. The protein content in cell lysates was determined using the BioRad Protein Assay Kit as recommended by the manufacturer.

In a second experiment, growth $\left(\mathrm{OD}_{600}\right)$ and GUS activity were monitored in P. syringae pv. tomato DC3000(pRGMU1) during a $5 \mathrm{~d}$ incubation period. DC3000(pRGMU1) was initially grown for $30 \mathrm{~h}$ on MG agar containing spectinomycin, resuspended in HSS medium $\left(\mathrm{OD}_{600}=0 \cdot 1\right)$ and incubated at $18{ }^{\circ} \mathrm{C}$ (250 r.p.m.). Aliquots of the fermentation (three replicates per time point) were removed at $0,6,12,24,48,72$ and $120 \mathrm{~h}$ after inoculation and evaluated for GUS activity as described above.

Plant inoculations. The virulence of $P$. syringae pv. tomato DC3000 and derivatives was evaluated on tomato (Lycopersicum esculentum cv. Glamour). Bacterial strains were grown for 48 h on MG agar with antibiotic selection. Bacterial cells were then resuspended in sterile distilled $\mathrm{H}_{2} \mathrm{O}$ to an $\mathrm{OD}_{600}$ of 0.5 and used to inoculate 3 -week-old tomato leaves by infiltration or with a spray inoculation method. In experiments where leaves were infiltrated, bacterial suspensions were adjusted to $10^{5}, 10^{6}, 10^{7}$ and $10^{8}$ c.f.u. $\mathrm{ml}^{-1}$ and the inoculum was delivered with a $1 \mathrm{ml}$ syringe. When plants were inoculated by spraying, bacterial cells $\left(10^{6}\right.$ c.f.u. $\left.\mathrm{ml}^{-1}\right)$ were applied to tomato leaves with an airbrush ( $\sim 8$ p.s.i.) until leaf surfaces were uniformly wet. Inoculated plants were incubated for $7 \mathrm{~d}$ in a growth chamber with a $12 \mathrm{~h}$ photoperiod at $24{ }^{\circ} \mathrm{C}$ with $48-51 \%$ relative humidity.

In experiments designed to follow the population dynamics in tomato, six plants were inoculated with each strain and incubated as described above. Random leaf samples (one leaf per plant, six leaves in total) were removed at each sampling time $(0,1,2,3,5$ and $7 \mathrm{~d}$ after inoculation). Leaves were weighed separately and macerated in a sterile saline solution $(0 \cdot 85 \% \mathrm{NaCl})$ using a mortar and pestle. Bacterial counts were determined by plating dilutions of the leaf homogenate onto MG amended with the appropriate antibiotics. Fluorescent colonies were counted after incubating the plates for $48 \mathrm{~h}$ and the experiment was performed twice.

Selected strains were tested for their ability to induce an HR on Nicotiana tabacum cv. Petite Havana using established methods (Schaad, 1988).

Susceptibility of plant tissue to COR. The susceptibility of tomato leaf tissue to COR was evaluated using 3-week-old plants of L. esculentum cv. Glamour. Tomato leaves (four replicates per concentration) were inoculated with $10 \mu \mathrm{l}$ solutions containing $0,0 \cdot 78,1 \cdot 56,3 \cdot 125,6 \cdot 25,12 \cdot 5,25,50$ or $100 \mathrm{ng}$ COR. Inoculated plants were incubated for $7 \mathrm{~d}$ in a growth chamber with a $12 \mathrm{~h}$ photoperiod at $24^{\circ} \mathrm{C}$ with $48-51 \%$ relative humidity.

Complementation experiments. pCPP2371 (containing hrpV) was transformed into DC3000-hrcC by electroporation. 
DC3000, DC3000-hrcC and DC3000-hrcC(pCPP2371) were incubated for $30 \mathrm{~h}$ on $\mathrm{MG}$ agar containing the appropriate antibiotics, resuspended in HSS medium to an $\mathrm{OD}_{600}$ of $0 \cdot 1$ and incubated at $18{ }^{\circ} \mathrm{C}(250$ r.p.m.). Aliquots of each strain $(0.5 \mathrm{ml}$; three replicates per sampling period) were removed $5 \mathrm{~d}$ after inoculation and evaluated for COR production.

\section{RESULTS}

\section{COR production by DC3000 and DC3000-hrcC}

Growth of both DC3000 and DC3000-hrcC was similar throughout the $10 \mathrm{~d}(240 \mathrm{~h}$ ) sampling period (Fig. 1a). In this experiment, the bacteria were grown in a minimal medium (HSS) at $18{ }^{\circ} \mathrm{C}$, conditions that are suboptimal for rapid growth. In DC3000, COR synthesis increased very slowly, reaching a maximal level of $1 \cdot 1 \mu \mathrm{g}$ COR $(\mathrm{mg}$ protein $)^{-1}$ at $240 \mathrm{~h}$ (Fig. 1b). In contrast, COR production by DC3000- $h r c C$ rose dramatically from 12 to $24 \mathrm{~h}$ and increased from $2 \cdot 4$ to $9 \cdot 7 \mu \mathrm{g}$ COR $(\mathrm{mg} \text { protein })^{-1}$ (Fig. 1b). COR production remained high in DC3000hrcC from 24 to $120 \mathrm{~h}$ and then decreased (Fig. 1b). These results clearly show that COR can be produced in vitro in the absence of a functional $h r c C$ gene. Since COR production by DC3000 is normally low in vitro, these results suggest that $\mathrm{COR}$ synthesis may be derepressed in DC3000-hrcC, especially in the earlier phases of the sampling period.
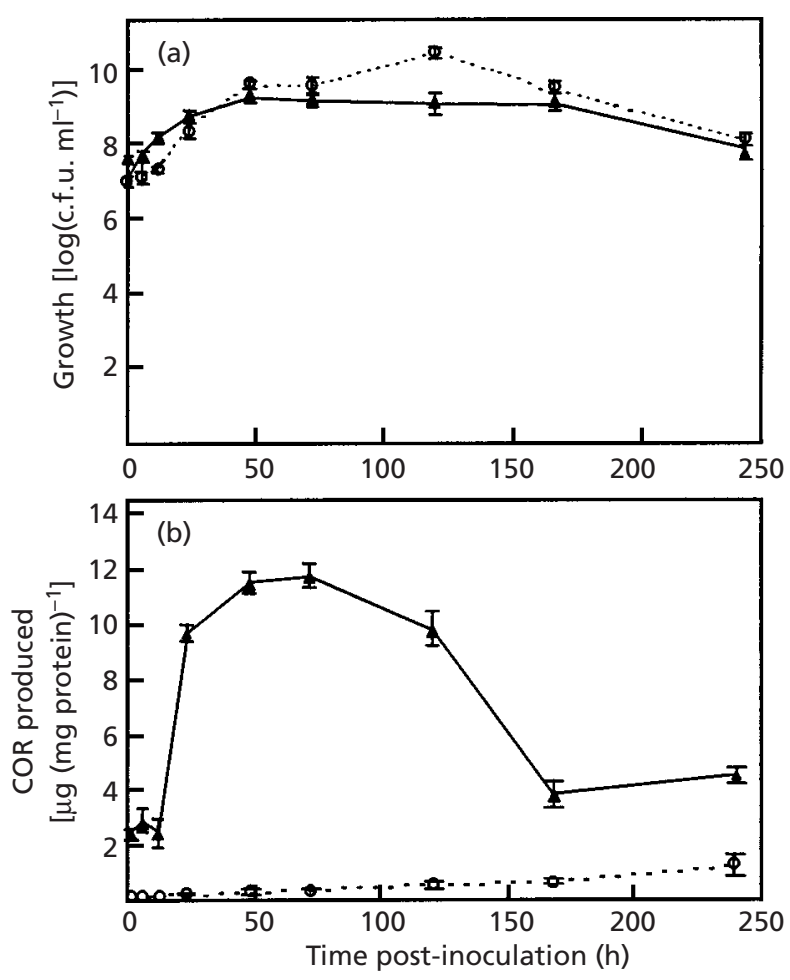

Fig. 1. Growth (a) and production of COR (b) by $P$. syringae pv. tomato DC3000 $(\bigcirc)$ and DC3000-hrcC $(\boldsymbol{\Delta})$. Values represent the means from one experiment of three replicates per strain and vertical bars indicate the SEM. The experiment was repeated with similar results.

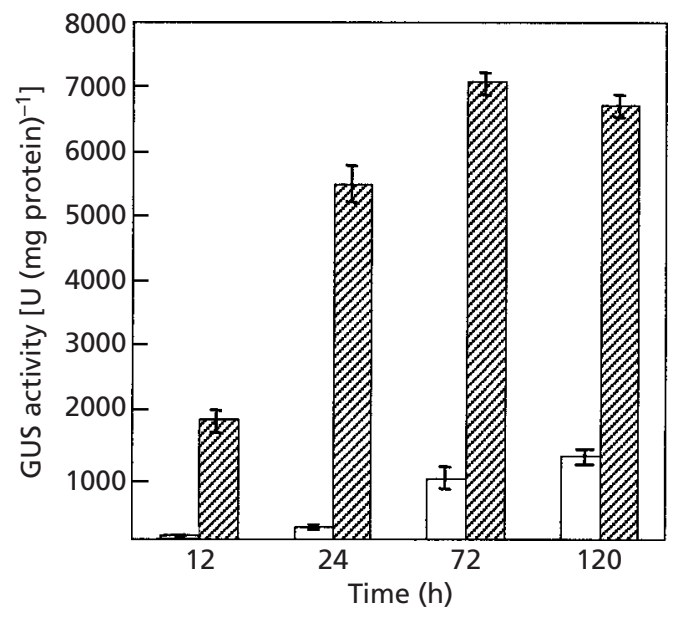

Fig. 2. Temporal expression of the cmaABT::uidA transcriptional fusion contained in pRGMU1 in $P$. syringae pv. tomato DC3000 (white bars) and DC3000-hrcC (hatched bars). Values represent the means from one experiment of three replicates per strain and vertical bars indicate the SEM. The experiment was repeated with similar results.

\section{COR gene expression in DC3000 and DC3000-hrcC}

To further analyse the effect of the $\operatorname{brcC}$ mutation on COR synthesis, we used transcriptional fusions to monitor COR gene expression in vitro. The gene fusion used in this analysis was the cmaABT::uidA fusion cloned in pRGMU1. The cmaABT transcript contains the structural genes for the biosynthesis of CMA, an intermediate in the pathway to COR. cmaABT expression in DC3000 correlated with COR production; for example, transcriptional activity in DC3000(pRGMU1) remained low and increased very slowly (from 45 to 1308 U GUS) during the sampling period (Fig. 2). In contrast, cmaABT expression in DC3000-hrcC increased rapidly from 1847 (12 h) to $6716 \mathrm{U}$ GUS (120 h) (Fig. 2). Therefore, the results obtained with the cmaABT transcriptional fusion correlated with the kinetics of COR production by these two strains.

\section{Plant inoculations}

Tomato plants were infiltrated with DC3000, DC3682 (COR ${ }^{-}$mutant) and DC3000-hrcC. When tomato plants were infiltrated with DC3000 at $10^{8}$ c.f.u. $\mathrm{ml}^{-1}$, a localized rapid, HR-like necrosis developed (data not shown). However, at inoculum concentrations of $10^{7}$, $10^{6}$ and $10^{5}$ c.f.u. $\mathrm{ml}^{-1}$, a necrotic, spreading lesion developed around the infiltration site and this was surrounded by a diffuse yellow chlorosis typical of COR production (Fig. 3a). In plants inoculated with the COR ${ }^{-}$ mutant DC3682, necrotic lesions developed but no chlorosis was detected regardless of the inoculum level (Fig. 3b). In leaves inoculated with DC3000-hrcC, a diffuse chlorosis was evident when leaves were infiltrated with $10^{8}, 10^{7}$ and $10^{6}$ c.f.u. $\mathrm{ml}^{-1}$, but necrotic lesions did 

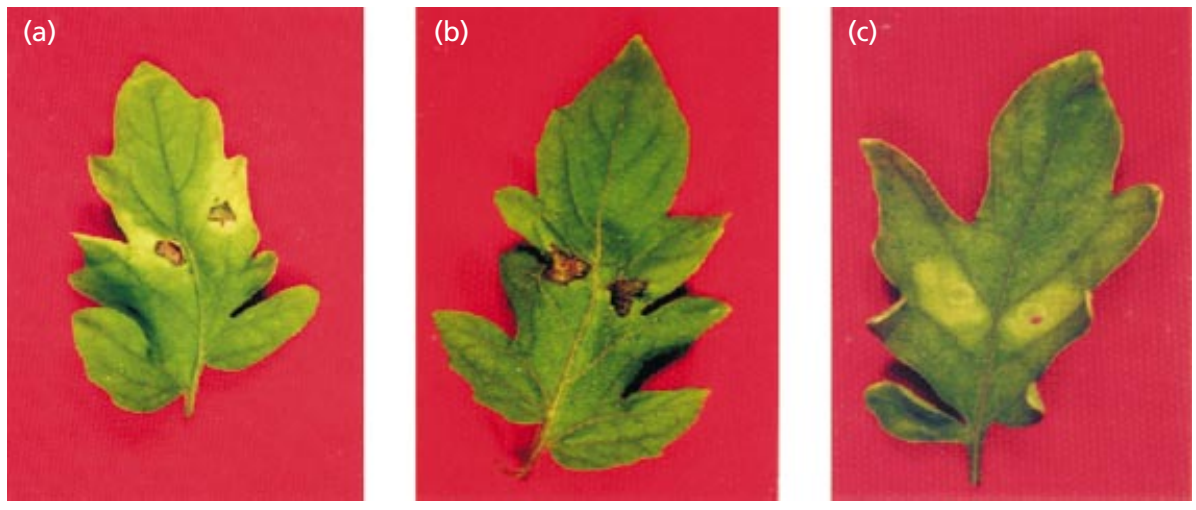

Fig. 3. Symptoms on tomato leaves infiltrated with $P$. syringae pv. tomato DC3000 (a), DC3682 (a COR ${ }^{-}$mutant of DC3000) (b) and DC3000-hrcC (c). Bacterial inoculum (106 c.f.u. $\mathrm{ml}^{-1}$ ) was infiltrated into leaves using a $1 \mathrm{ml}$ syringe without a needle. After inoculation, all plants were incubated in a growth chamber with a $12 \mathrm{~h}$ photoperiod at $24{ }^{\circ} \mathrm{C}$ with $48-51 \%$ relative humidity. Photographs were taken $7 \mathrm{~d}$ after infiltration.
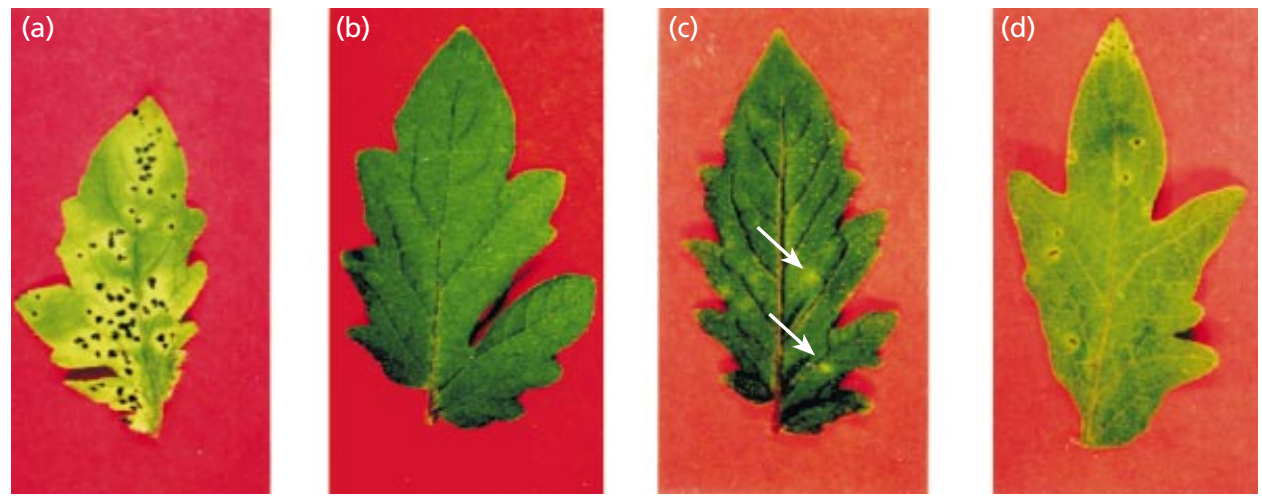

Fig. 4. Tomato leaves sprayed with $P$. syringae pv. tomato $D C 3000$ (a), $D C 3682$ (a COR ${ }^{-}$mutant of $\left.D C 3000\right)(b), D C 3000-$

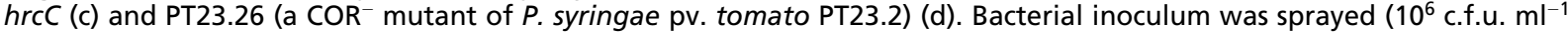
at $\sim 8$ p.s.i.) onto tomato leaves until surfaces were uniformly wet. After inoculation, all plants were incubated in a growth chamber as described in the legend to Fig. 3 and photographed $7 \mathrm{~d}$ after inoculation. The arrows in (c) show the location of chlorotic haloes on plants inoculated with DC3000-hrcC.

not develop (Fig. 3c). No chlorosis developed when DC3000-hrcC was inoculated at $10^{5}$ c.f.u. $\mathrm{ml}^{-1}$ (data not shown), indicating that the inoculum density used for infiltration was a critical factor in obtaining the chlorotic reaction indicative of COR production.

Tomato plants sprayed with $P$. syringae pv. tomato DC3000 developed the typical symptoms of bacterial speck disease, which include necrotic lesions surrounded by a diffuse chlorotic halo (Fig. 4a). In contrast, tomato leaves inoculated with the $\mathrm{COR}^{-}$mutant DC3682 (Fig. $4 \mathrm{~b})$ remained symptomless for the duration of the experiment. Leaves inoculated with DC3000-hrcC developed small chlorotic haloes without necrosis, which suggested that COR was produced in planta (Fig. 4c). Tomato leaves were also spray-inoculated with $P$. syringae pv. tomato PT23.26, a $\mathrm{COR}^{-}$mutant characterized in previous studies (Bender et al., 1989, 1991). Unlike DC3682, PT23.26 produced visible necrotic lesions on tomato leaves (Fig. 4d). Although the lesions were surrounded by a faint chlorotic region, they lacked the diffuse chlorosis typical of COR production (as shown in Fig. 4a).

\section{Population dynamics in tomato leaves}

DC3000, DC3000-hrcC, DC3682 and PT23.26 were inoculated into tomato leaves by spraying (see Methods) and the bacterial populations were monitored over a $7 \mathrm{~d}$ period (Fig. 5). The population of $P$. syringae pv. tomato DC3000 on day 0 was $5 \cdot 2 \times 10^{5}$ c.f.u. $\mathrm{ml}^{-1}$; growth of this strain increased steadily over the sampling period and was approximately 1000 -fold higher $\left(8.6 \times 10^{8}\right.$ c.f.u. $\mathrm{ml}^{-1}$ ) at the end of the sampling period (day 7 ; Fig. 5). The population of DC3000- $h r c C$ was approximately $5.5 \times 10^{5}$ c.f.u. $\mathrm{ml}^{-1}$ on day 0 ; however, this strain failed to multiply in planta and the population was 1000 -fold lower than the wild-type DC3000 on day 7 (Fig. 5). Interestingly, the COR mutant, DC3682, did not multiply in planta and the population at day 7 was only 


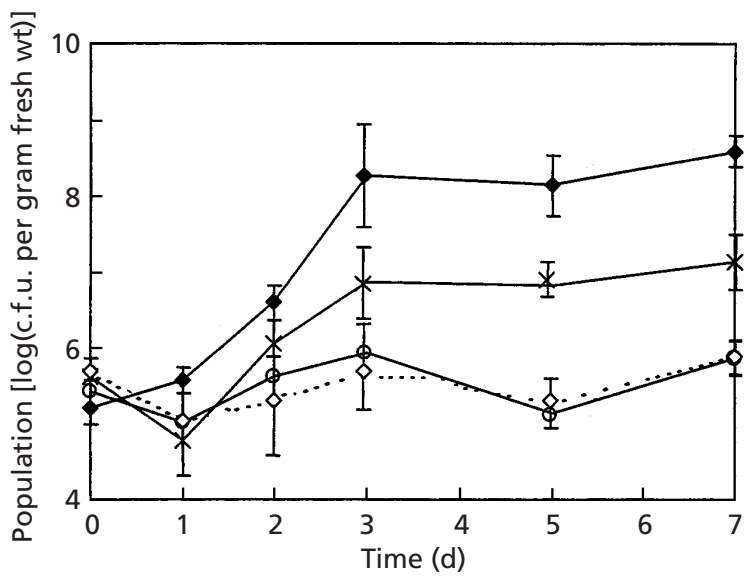

Fig. 5. Population dynamics of $P$. syringae pv. tomato $D C 3000$ $(\diamond), \mathrm{DC} 3000-h r c C(\diamond), \mathrm{DC} 3682\left(\mathrm{COR}^{-}\right.$mutant of DC3000) $(\bigcirc)$ and PT23.26 (COR mutant of PT23.2) $(x)$ in tomato tissue. Bacterial inoculum $\left(10^{6}\right.$ c.f.u. $\left.\mathrm{ml}^{-1}\right)$ was sprayed ( $\sim 8$ p.s.i.) onto tomato leaves until surfaces were uniformly wet and plants were incubated in a growth chamber as described in the legend to Fig. 3. Bacterial populations were determined by homogenizing the leaves in sterile saline $(0.85 \% \mathrm{NaCl})$ followed by dilution plating. All experiments were performed twice with similar results and vertical bars indicate the SEM.

$5 \cdot 8 \times 10^{5}$ c.f.u. $\mathrm{ml}^{-1}$. However, PT23.26, which produced lesions in the absence of COR (Fig. 4d), did multiply in planta and attained a population of $7 \cdot 1 \times$ $10^{7}$ c.f.u. $\mathrm{ml}^{-1}$, which is only 12 -fold lower than DC3000 (Fig. 5). PT23.26 is a Tn5 insertion mutant of the $\mathrm{COR}^{+}$ strain, P. syringae pv. tomato PT23.2 (Bender et al., 1989).

\section{Restoration of normalized COR production to DC3000-hrcC}

Our results clearly indicated that the expression and production of COR in DC3000- $h r c C$ occurred earlier and at higher levels than DC3000. Such a phenotype could result from the inactivation of $h r c C$ and/or the disruption of $h r p V$, a known regulatory gene that maps downstream of $h r c C$ in the same transcriptional unit. The first possibility was examined by measuring COR production in CUCPB5112, which contains a non-polar mutation in $\mathrm{brcC}$. At $5 \mathrm{~d}(120 \mathrm{~h})$ after inoculation, CUCPB5112 produced $1.72 \mu \mathrm{g}$ COR (mg protein) ${ }^{-1}$, a level similar to that obtained with DC3000 $[1 \cdot 0-2 \cdot 5 \mu \mathrm{g}$ COR (mg protein $)^{-1}$ ] and significantly lower than that obtained with DC3000-hrcC [9.0-10.5 $\mu$ g COR (mg protein $)^{-1}$. These results indicated that the inactivation of $h r c C$ was not the reason for elevated COR production in DC3000-hrcC and suggested that the Tn5Cm mutation in DC3000-hrcC had polar effects on downstream genes. Therefore, complementation experiments with the regulatory gene $h r p V$ were performed with the aim of restoring the low-level, wild-type production of COR to DC3000-hrcC. Construct pCPP2371 (containing $h r p V)$ was introduced into DC3000-hrcC and COR

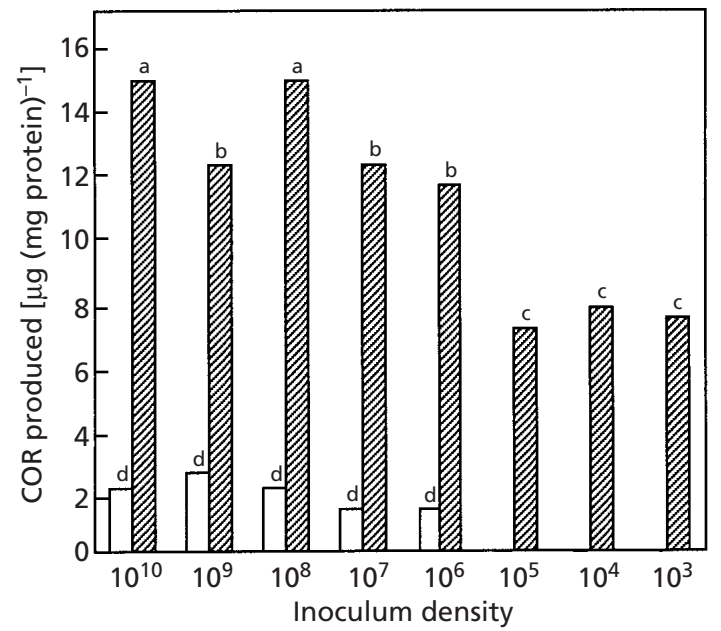

Fig. 6. Inoculum density and COR production. $P$. syringae pv. tomato DC3000 (white bars) and DC3000-hrcC (hatched bars) were inoculated into HSS broth at concentrations ranging from $10^{3}$ to $10^{10}$ c.f.u. $\mathrm{ml}^{-1}$, incubated for $72 \mathrm{~h}$ at $18^{\circ} \mathrm{C}$ and analysed for COR production by HPLC fractionation of organic acid extracts (Palmer \& Bender, 1993). Values represent the means from experiments containing three replicate cultures and values indicated by the same lower-case letter were not significantly different at $P=0.01$ as determined by Duncan's Multiple Range Test. COR was not detected in DC3000 when the initial inoculum density was $10^{3}-10^{5}$ c.f.u. $\mathrm{ml}^{-1}$. The detection limit for COR by HPLC was $100 \mathrm{ng}$ (Rangaswamy et al., 1998). The experiment was repeated with similar results.

production was evaluated at $5 \mathrm{~d}$. Using this approach, the mean amount of COR produced by DC3000, DC3000- $h r c C$ and DC3000- $h r c C($ pCPP2371) was 0.9, $7 \cdot 1$ and $0 \cdot 7 \mu \mathrm{g}$ COR (mg protein) $)^{-1}$, respectively. These data were statistically analysed using Duncan's Multiple Range Test and the amounts of COR produced by DC3000 and DC3000-hrcC(pCPP2371) were not significantly different at $P=0 \cdot 01$. However, COR production by DC3000-hrcC was significantly higher than DC3000 and DC3000-hrcC(pCPP2371), suggesting that hrpV restored the wild-type level of COR to DC3000-brcC when expressed in trans.

\section{COR production as a function of inoculum density}

Our results suggested that COR production in DC3000 gradually increased with time but remained low throughout the sampling period (Fig. 1b). However, in DC3000-hrcC, COR production increased rapidly and was 75 -fold higher than DC3000 when measured $24 \mathrm{~h}$ after inoculation (Fig. 1b). To evaluate whether the initial inoculum density had an effect on COR production, different starting concentrations of bacterial cells were inoculated in HSS broth and COR production was evaluated at $72 \mathrm{~h}$. When the initial inoculum density was $10^{6}-10^{10}$ c.f.u. $\mathrm{ml}^{-1}$, COR was detected in DC3000 at $72 \mathrm{~h}$ and the concentration ranged from 1.3 to $2.4 \mu \mathrm{g}$ COR (mg protein $)^{-1}$ (Fig. 6). However, when the initial inoculum density was $10^{5}$ c.f.u. $\mathrm{ml}^{-1}$ or lower, COR 
could not be detected in DC3000 (Fig. 6). It should be noted that our detection limit for COR by HPLC was 100 ng (Rangaswamy et al., 1998). In contrast, COR was detected in DC3000-hrcC irrespective of the initial inoculum density and the amount of COR produced at $72 \mathrm{~h}$ ranged from 7 to $14 \mu \mathrm{g}$ COR (mg protein) ${ }^{-1}$ (Fig. 6).

\section{DISCUSSION}

\section{Cross-talk between the $h r p$ and cor gene clusters}

In this study, DC3000-hrcC and CUCPB5112, which contain polar and non-polar mutations in $b r c C$, respectively, were evaluated for COR production. CUCPB5112 produced COR at levels comparable to the wild-type, which establishes that a functional hrp secretion system is not required for COR production in DC3000. However, DC3000- $h r c C$ overproduced COR relative to DC3000 and the wild-type level of COR was restored to this mutant when $\operatorname{brpV}$ was expressed in trans. The role of $\mathrm{HrpV}$ as a negative regulator of the hrp regulon has been established (Deng et al., 1998; Preston et al., 1998) and the results of the present study suggest that hrpV may have a regulatory effect on COR production in DC3000. This hypothesis will be pursued by constructing a defined mutation within the hrpV gene of DC3000 and analysing the mutant for COR production and cor gene expression. Preliminary results have indicated that mutations in the hrpS gene of DC3000 also have an impact on COR production. A DC3000 hrpS mutant (Yuan \& He, 1996) produced tenfold more COR and showed elevated levels of cor gene expression relative to the wild-type DC3000 (Preston, 1997). The kinetics of COR production by DC3000-hrpS were similar to DC3000-hrcC in the early phases of the fermentation and high levels of COR were produced by both strains $24 \mathrm{~h}$ after inoculation (Fig. 1b; A. Peñaloza-Vázquez \& C. L. Bender, unpublished). Therefore, in addition to $\operatorname{hrpV}$, other genes (such as hrpS) may be involved in some form of cross-talk with the COR biosynthetic cluster.

It is possible that a direct regulatory connection exists between the hrp and cor gene clusters that can be analysed and dissected using molecular approaches. One gene that is required for expression of both the $h r p$ and cor gene clusters is rpoN, which encodes $\sigma^{54}$. Transcriptional initiation by RNA polymerase utilizing $\sigma^{54}$ requires an activator protein, and among the beststudied $\sigma^{54}$-dependent activators are $\mathrm{NtrC}$ and NifA (Morett \& Segovia, 1993; North et al., 1993). Both HrpR and HrpS show sequence similarity with NtrC (Grimm et al., 1995; Xiao et al., 1994), suggesting a role for $\sigma^{54}$ in transcription of the hrp cluster. Xiao et al. (1994) demonstrated that the hrpL gene product, which belongs to the extracellular factor subfamily of $\sigma$ factors, contains a promoter region with strong homology to the consensus recognized by $\sigma^{54}$. Furthermore, Hendrickson et al. (2000a) showed that $\sigma^{54}$ is required for the transcription of hrpL in $P$. syringae pv. maculicola. The alternative $\sigma$ factor encoded by $h r p L$ has a critical role in hrp gene expression and is required for the expression of several transcripts in the $h r p / h r c$ gene cluster (Hutcheson et al., 1996).

rpoN mutants of $P$. syringae pv. maculicola ES4326 and pv. glycinea PG4180 were unable to synthesize COR and were defective in transcriptional activation of the CFA and cmaABT promoters (Hendrickson et al., 2000b; F. Alarcón-Chaidez \& C. L. Bender, unpublished). Interestingly, the cor gene transcripts in PG4180 lack the consensus sequence recognized by $\sigma^{54}$, but contain enhancer-binding sequences recognized by $\mathrm{NtrC}$ and NifA activator proteins (Liyanage et al., 1995; Ullrich \& Bender, 1994). Although the role of $\sigma^{54}$ in the synthesis of COR by DC3000 remains unclear, it is tempting to speculate that $\sigma^{54}$ may function in some way to coordinately regulate $h r p$ and cor gene expression in this strain.

\section{hrp and cor mutants of DC3000 fail to multiply in planta}

In experiments where exogenous COR was added to tomato leaves, chlorosis was induced with only $0.078 \mathrm{ng}$ of purified phytotoxin. When DC3000-hrcC was inoculated into tomato leaves by infiltration, a chlorotic zone was produced, suggesting that sufficient COR was present or produced in the plant to initiate chlorosis (Fig. 3c). Small chlorotic haloes also developed on tomato leaves spray-inoculated with DC3000-hrcC (Fig. 4c); however, it is important to note that COR production did not enable DC3000-hrcC to multiply in planta and cause typical disease symptoms.

When the $\mathrm{COR}^{-}$mutant DC3682 was inoculated by spraying, no symptoms were observed on tomato leaves (Fig. 4b). Furthermore, this mutant did not multiply in the host and the bacterial population was 1000 -fold lower than the wild-type DC3000 at the end of the $7 \mathrm{~d}$ sampling period (Fig. 5). Further characterization of DC3682 showed that this mutant elicited an HR on tobacco leaves (data not shown), indicating that DC3682 contains a functional type III secretion system. DC3682 was complemented for COR production by cosmid pEC18, which contains the CFA gene cluster (Ma et al., 1991; A. Peñaloza-Vázquez \& C. L. Bender, unpublished). The inactivation of the CFA gene cluster in DC3682 eliminated the ability of this mutant to synthesize COR, CFA and phytotoxic analogues of COR (A. Peñaloza-Vázquez \& C. L. Bender, unpublished).

The results obtained with DC3682 in this study agree with an earlier report where Arabidopsis and tomato plants were inoculated with DC3661, another $\mathrm{COR}^{-}$ mutant of DC3000 (Ma et al., 1991; Mittal \& Davis, 1995). Symptoms did not develop with DC3661 on either host when plants were inoculated by dipping leaves into bacterial suspensions and multiplication of the $\mathrm{COR}^{-}$ mutant was several logs lower than DC3000 (Mittal \& Davis, 1995). In contrast, when DC3661 was infiltrated into host plants, necrotic lesions developed and the bacteria multiplied to levels approaching the wild-type DC3000. Mittal \& Davis (1995) concluded that COR 
was required during the early stages of infection and presented data demonstrating that COR inhibited the host defence response in Arabidopsis. Apparently, COR was ineffectual in suppressing host defence when bacterial cells were directly infiltrated into plant tissue (Mittal \& Davis, 1995). These results are consistent with those obtained in the present study, although it remains unclear whether COR functions to inhibit defence in tomato tissue.

Interestingly, the $\mathrm{COR}^{-}$mutant PT23.26, which also contains a Tn5 insertion in the CFA gene cluster, produced visible necrotic lesions on tomato leaves (Fig. $4 \mathrm{~d}$ ) and the population was only 12-fold lower than DC3000 (Fig. 5). These results agree with a previous study where we examined the role of COR in $P$. syringae pv. tomato PT23.2. $\mathrm{COR}^{-}$mutants of PT23.2 produced visible necrotic lesions on tomato leaves when inoculated by spraying and the population of $\mathrm{COR}^{-}$ mutants was only tenfold lower than the wild-type in planta (Bender et al., 1987). We concluded that COR functioned as a virulence factor in P. syringae pv. tomato PT23.2 by enhancing multiplication and lesion expansion in planta. However, the results obtained in the present study suggest that COR is required for the successful infection of tomato leaves by DC3000. Therefore, the importance and role of COR varies in $P$. syringae pv. tomato DC3000 and PT23.2. One possible explanation for this disparity is the location of the COR biosynthetic gene cluster in these two strains; the COR gene cluster in PT23.2 is borne on a $101 \mathrm{~kb}$ plasmid, designated pPT23A (Bender et al., 1989), whereas COR is chromosomally encoded in DC3000 (Moore et al., 1989). In our experience, pPT23A is inherently unstable (Bender et al., 1992), a phenomenon consistent with the role of COR as a dispensable virulence factor. Furthermore, pathogenic strains of $P$. syringae pv. tomato have been identified that do not produce COR (Mitchell et al., 1983). Therefore, it is possible that PT23.2 acquired the COR plasmid, pPT23A, after it became pathogenic. However, the chromosomally encoded COR gene cluster in DC3000 may have co-evolved with the hrp/hrc secretion system and the requirement for $\mathrm{COR}$ in the establishment of a successful infection may reflect this.

\section{COR production in DC3000-hrcC is derepressed or constitutively up-regulated}

In the wild-type strain, DC3000, COR production and COR gene expression increased with time (Figs $1 \mathrm{~b}$ and 2) and expression of the cmaABT operon increased during exponential phase (data not shown). However, in DC3000-hrcC, COR production was not a function of growth phase (Fig. 1b) or the initial inoculum concentration (Fig. 6). These results suggest that COR production is derepressed or up-regulated in DC3000brcC, presumably because of the polar effects of the Tn5Cm mutation on hrpV. It is also important to note that the overproduction of COR in DC3000-hrcC did not increase the ability of the bacteria to colonize the host (Fig. 6), even though this would provide a biological rationale for the observed phenomenon. In conclusion, this study indicates that a regulatory connection exists between the type III Hrp secretion system and COR biosynthesis. The identification of the regulatory circuitry that connects the two systems warrants further investigation and will improve our understanding of bacterial pathogenesis.

\section{ACKNOWLEDGEMENTS}

C.L.B. acknowledges support for this project from the Oklahoma Agricultural Experiment Station and National Science Foundation grant MCB 96-03618. This research was also supported in part by NSF grant MCB 97-35303-4488 to A. C. We thank Lisa Keith for reviewing the manuscript prior to submission.

\section{REFERENCES}

Alfano, J. R., Charkowski, A. O., Deng, W.-L., Badel, J. L., PetnickOcwieja, T., van Dijk, K. \& Collmer, A. (2000). The Pseudomonas syringae Hrp pathogenicity island has a tripartite mosaic structure composed of a cluster of type III secretion genes bounded by exchangeable effector and conserved effector loci that contribute to parasitic fitness and pathogenicity in plants. Proc Natl Acad Sci U S A 97, 4856-4861.

Bender, C. L., Stone, H. E., Sims, J. J. \& Cooksey, D. A. (1987). Reduced pathogen fitness of Pseudomonas syringae pv. tomato Tn5 mutants defective in coronatine production. Physiol Mol Plant Pathol 30, 272-283.

Bender, C. L., Malvick, D. K. \& Mitchell, R. E. (1989). Plasmidmediated production of the phytotoxin coronatine in Pseudomonas syringae pv. tomato. J Bacteriol 171, 807-812.

Bender, C. L., Young, S. A. \& Mitchell, R. E. (1991). Conservation of plasmid DNA sequences in coronatine-producing pathovars of Pseudomonas syringae. Appl Environ Microbiol 57, 993-999.

Bender, C. L., Young, S. A. \& Mitchell, R. E. (1992). Ecological and genetic studies of coronatine synthesis in Pseudomonas syringae. In Pseudomonas: Molecular Biology and Biotechnology, pp. 56-63. Edited by E. Galli, S. Silver \& B. Witholt. Washington, DC: American Society for Microbiology.

Bender, C. L., Alarcón-Chaidez, F. \& Gross, D. C. (1999). Pseudomonas syringae phytotoxins: mode of action, regulation and biosynthesis by peptide and polyketide synthetases. Microbiol Mol Biol Rev 63, 266-292.

Bogdanove, A. J., Beer, S. V., Bonas, U. \& 8 other authors (1996). Unified nomenclature for broadly conserved hrp genes of phytopathogenic bacteria. Mol Microbiol 20, 681-683.

Charkowski, A. O., Huang, H.-C. \& Collmer, A. (1997). Altered localization of HrpZ in Pseudomonas syringae pv. syringae hrp mutants suggests that different components of the Type III secretion pathway control protein translocation across the inner and outer membranes of Gram-negative bacteria. J Bacteriol 179, 3866-3874.

Deng, W. L., Preston, G., Collmer, A., Chang, C.-J. \& Huang, H.-C. (1998). Characterization of the hrpC and hrpRS operons of Pseudomonas syringae pathovars syringae, tomato and glycinea and analysis of the ability of $h r p F, h r p G, h r p T$, and $h r p V$ mutants to elicit the hypersensitive response and disease in plants. J Bacteriol 180, 4523-4531.

Galán, J. E. \& Collmer, A. (1999). Type III secretion machines: bacterial devices for protein delivery into host cells. Science 284, 1322-1328. 
Grimm, C., Aufsatz, W. \& Panopoulos, N. J. (1995). The hrpRS locus of Pseudomonas syringae pv. phaseolicola constitutes a complex regulatory unit. Mol Microbiol 15, 155-165.

He, S. Y. (1998). Type III protein secretion systems in plant and animal pathogenic bacteria. Annu Rev Phytopathol 36, 363-392.

Hendrickson, E. L., Guevera, P. \& Ausubel, F. M. (2000a). The alternative sigma factor $\mathrm{RpoN}$ is required for hrp activity in Pseudomonas syringae pathovar maculicola and acts at the level of hrpL transcription. J Bacteriol 182, 3508-3516.

Hendrickson, E. L, Guevera, P., Shao, J., Peñaloza-Vázquez, A., Bender, C. \& Ausubel, F. M. (2000b). Virulence of the phytopathogen Pseudomonas syringae pathovar maculicola is rpoN dependent. J Bacteriol 182, 3498-3507.

Hirano, S. S., Charkowski, A. O., Collmer, A., Willis, D. K. \& Upper, C. D. (1999). Role of the Hrp type III protein secretion system in growth of Pseudomonas syringae pv. syringae $\mathrm{B} 728 \mathrm{a}$ on host plants in the field. Proc Natl Acad Sci U S A 96, 9851-9856.

Hrabak, E. M. \& Willis, D. K. (1992). The lemA gene required for pathogenicity of Pseudomonas syringae pv. syringae on bean is a member of a family of two-component regulators. J Bacteriol 174, 3011-3020.

Hutcheson, S. W. (1999). The hrp cluster of Pseudomonas syringae: a pathogenicity island encoding a type III protein translocation complex? In Pathogenicity Islands and Other Mobile Virulence Elements, pp. 309-329. Edited by J. B. Kaper \& J. Hacker. Washington, DC: American Society for Microbiology.

Hutcheson, S. W., Heu, S., Jin, S., Lidell, M. C., Pirhonen, M. U. \& Rowley, D. L. (1996). Function and regulation of Pseudomonas hrp genes. In Molecular Biology of Pseudomonads, pp. 512-521. Edited by T. Nakazawa, K. Furukawa, D. Haas \& S. Silver. Washington, DC: American Society for Microbiology.

Keane, P. J., Kerr, A. \& New, P. B. (1970). Crown gall of stone fruit. II. Identification and nomenclature of Agrobacterium isolates. Aust J Biol Sci 23, 585-595.

Kenyon, J. S. \& Turner, J. G. (1992). The stimulation of ethylene synthesis in Nicotiana tabacum leaves by the phytotoxin coronatine. Plant Physiol 100, 219-224.

King, E. O., Ward, M. K. \& Raney, D. E. (1954). Two simple media for the demonstration of pyocyanin and fluorescein. J Lab Clin Med 44, 301-307.

Kitten, T., Kinscherf, T. G., McEvoy, J. L. \& Willis, D. K. (1998). A newly identified regulator is required for virulence and toxin production in Pseudomonas syringae. Mol Microbiol 28, 917-929.

Liyanage, H., Penfold, C., Turner, J. \& Bender, C. L. (1995). Sequence, expression and transcriptional analysis of the coronafacate ligase-encoding gene required for coronatine biosynthesis by Pseudomonas syringae. Gene 153, 17-23.

Ma, S.-W., Morris, V. L. \& Cuppels, D. A. (1991). Characterization of a DNA region required for production of the phytotoxin coronatine by Pseudomonas syringae pv. tomato. Mol PlantMicrobe Interact 4, 69-74.

Mitchell, R. E. (1985). Coronatine biosynthesis: incorporation of $\mathrm{L}-\left[\mathrm{U}-{ }^{14} \mathrm{C}\right]$ isoleucine and $\mathrm{L}-\left[\mathrm{U}-{ }^{14} \mathrm{C}\right]$ threonine into the 1 -amido-1carboxy-2-ethylcyclopropyl moiety. Phytochemistry 24, 247-249.

Mitchell, R. E., Hale, C. N. \& Shanks, J. C. (1983). Production of different pathogenic symptoms and different toxins by strains of Pseudomonas syringae pv. tomato not distinguishable by gelimmunodiffusion assay. Physiol Plant Pathol 23, 315-322.

Mittal, S. M. \& Davis, K. R. (1995). Role of the phytotoxin coronatine in the infection of Arabidopsis thaliana by Pseudomonas syringae pv. tomato. Mol Plant-Microbe Interact 8, 165-171.
Moore, R. A., Starratt, A. N., Ma, S.-W., Morris, V. L. \& Cuppels, D. A. (1989). Identification of a chromosomal region required for biosynthesis of the phytotoxin coronatine by Pseudomonas syringae pv. tomato. Can J Microbiol 35, 910-917.

Morett, E. \& Segovia, E. (1993). The $\sigma^{54}$ bacterial enhancerbinding protein family: mechanism of action and phylogenetic relationship of their functional domains. J Bacteriol 175, 6067-6074.

North, A. K., Klose, K. E., Stedman, K. M. \& Kustu, S. (1993). Prokaryotic enhancer-binding proteins reflect eukaryote-like modularity: the puzzle of nitrogen regulatory protein C. J Bacteriol 175, 4267-4273.

Palmer, D. A. \& Bender, C. L. (1993). Effects of environmental and nutritional factors on production of the polyketide phytotoxin coronatine by Pseudomonas syringae pv. glycinea. Appl Environ Microbiol 59, 1619-1626.

Palmer, D. A., Bender, C. L. \& Sharma, S. (1997). Use of Tn5-gusA5 to investigate environmental and nutritional effects on gene expression in the coronatine biosynthetic gene cluster of Pseudomonas syringae pv. glycinea. Can J Microbiol 43, 517-525.

Parry, R. J., Mhaskar, S. V., Lin, M.-T., Walker, A. E. \& Mafoti, R. (1994). Investigations of the biosynthesis of the phytotoxin coronatine. Can J Chem 72, 86-99.

Peñaloza-Vázquez, A. \& Bender, C. L. (1998). Characterization of CorR, a transcriptional activator which is required for biosynthesis of the phytotoxin coronatine. J Bacteriol 180, 6252-6259.

Preston, G. (1997). HrpZ and hrp expression in Pseudomonas syringae and emerging paradigms of pathogenesis and host specificity. PhD thesis, Cornell University, USA.

Preston, G., Deng, W.-L., Huang, H.-C. \& Collmer, A. (1998). Negative regulation of hrp genes in Pseudomonas syringae by HrpV. J Bacteriol 180, 4532-4537.

Rangaswamy, V., Mitchell, R., Ullrich, M. \& Bender, C. (1998). Analysis of genes involved in the biosynthesis of coronafacic acid, the polyketide component of the phytotoxin coronatine. J Bacteriol 180, 3330-3338.

Rich, J. J., Kinscherf, T. G., Kitten, T. \& Willis, D. K. (1994). Genetic evidence that the gacA gene encodes the cognate response regulator for the lemA sensor in Pseudomonas syringae. J Bacteriol 176, 7468-7475.

Rohde, B. H., Pohlack, B. \& Ullrich, M. S. (1998). Occurrence of thermoregulation of genes involved in coronatine biosynthesis among various Pseudomonas syringae strains. J Basic Microbiol 38, 41-50.

Roine, E., Wei, W., Yuan, J., Nurmiaho-Lassila, E. L., Kalkkinen, N., Romantschuk, M. \& He, S. Y. (1997). Hrp pilus: an hrpdependent bacterial surface appendage produced by Pseudomonas syringae pv. tomato DC3000. Proc Natl Acad Sci U S A 94, 3459-3464.

Sambrook, J., Fritsch, E. F. \& Maniatis, T. (1989). Molecular Cloning: a Laboratory Manual, 2nd edn. Cold Spring Harbor, NY : Cold Spring Harbor Laboratory.

Schaad, N. W. (1988). Laboratory Guide for Identification of Plant Pathogenic Bacteria. St Paul, MI: American Phytopathological Society Press.

Ullrich, M. \& Bender, C. L. (1994). The biosynthetic gene cluster for coronamic acid, an ethylcyclopropyl amino acid, contains genes homologous to amino acid activating enzymes and thioesterases. J Bacteriol 176, 7574-7586.

Ullrich, M., Peñaloza-Vázquez, A., Bailey, A. M. \& Bender, C. L. (1995). A modified two-component regulatory system is involved 
in temperature-dependent biosynthesis of the Pseudomonas syringae phytotoxin coronatine. J Bacteriol 177, 6160-6169.

Wang, L., Bender, C. L. \& Ullrich, M. S. (1999). The transcriptional activator CorR is involved in biosynthesis of the phytotoxin coronatine and binds to the $c m a A B T$ promoter region in a temperature-dependent manner. Mol Gen Genet 262, 250-260.

Wei, W., Plovanich-Jones, A., Deng, W.-L., Jin, Q.-L., Collmer, A., Huang, H.-C. \& He, S. Y. (2000). The gene coding for the Hrp pilus structural protein is required for type III secretion of Hrp and Avr proteins in Pseudomonas syringae pv. tomato. Proc Natl Acad Sci USA 97, 2247-2252.

Xiao, Y., Heu, S., Yi, J., Lu, Y. \& Hutcheson, S. W. (1994). Identification of a putative alternate sigma factor and characterization of a multicomponent regulatory cascade controlling the expression of Pseudomonas syringae pv. syringae Pss61 hrp and hrmA genes. J Bacteriol 176, 1025-1036.

Yu, J., Peñaloza-Vázquez, A., Chakrabarty, A. M. \& Bender, C. L. (1999). Involvement of the exopolysaccharide alginate in the virulence and epiphytic fitness of Pseudomonas syringae pv. syringae. Mol Microbiol 33, 712-720.

Yuan, J. \& He, S. Y. (1996). The Pseudomonas syringae Hrp regulation and secretion system controls the production and secretion of multiple extracellular proteins. J Bacteriol 178, 6399-6402.

Received 22 March 2000; revised 4 August 2000; accepted 7 August 2000. 